\title{
PCLO Gene
}

National Cancer Institute

\section{Source}

National Cancer Institute. PCLO Gene. NCI Thesaurus. Code C118213.

This gene is involved in the organization of proteins at the synapse. 